\title{
The Role of Media Literacy in the Public Relations: What Is Happening in the Portuguese Universities?
}

\author{
Rita Monteiro Mourão ${ }^{1}$, Sandra Lopes Miranda ${ }^{2}$ \\ ${ }^{1}$ ISCTE-IUL and ESCS-IPL, Portugal \\ ${ }^{2}$ ESCS-IPL and CIES-IUL, Portugal \\ Correspondence: Rita Monteiro Mourão, ISCTE-IUL and ESCS-IPL; Lisbon, Portugal, Campus de Benfica do IPL: \\ 1549-014-Lisboa; Department of Human Sciences. Lisbon, Portugal. E-mail: rita_andreia_mourao@iscte-iul.pt or \\ rmourao@escs.ipl.pt
}

Received: May 24, 2020

Accepted: Nov. 12, 2020

Online Published: Nov. 16, 2020

doi:10.11114/smc.v8i2.5079

URL: https://doi.org/10.11114/smc.v8i2.5079

\begin{abstract}
Media literacy has a key role in education. It is known that the public relations profession often involves a position of media relations. In this context, this type of expert must obtain skills in the critical and active use of media. Afterwards it arises the need to understand what kind of investment in media literacy has been done by Portuguese Public Universities. This will be the objective of this exploratory qualitative study. For the collection of information, we have proceeded to the analysis of the curricula of Degree's and master's degree in Public Relations courses of 15 Portuguese Public Universities. In general, it was concluded that there is still little investment at this level. Of the 15 Portuguese public universities analyzed, only three universities hold courses on media education in their curricula, within the degree in public relations / organizational communication / strategic communication. Regarding to the master's degree we found that only four of the 15 Portuguese Public Universities consider the media literacy in their curricula. This research focuses specifically in Public Universities. However, in future studies it will be also important to include private universities to compare the main differences.
\end{abstract}

Keywords: media literacy, public relations, higher education, Portuguese public universities

\section{Introduction}

The literacy have been seen as a dimension of the new civilization, after the industrial revolution. In this context, this ability to work with words and images is relevant for the transmission of information and knowledge, being as a form of social hegemony. It is known that, today, $90 \%$ of the population belonging to developed countries is literate. This is because, as a rule, individuals develop their basic skills in reading, writing and calculation since the primary school (Perez-Tornero and Varis, 2010). However, new skills have begun to be required, mainly regarding aspects related to media coverage of the image and audiovisual language. It this context we must acquire the understanding of what is currently considered to be referred to media literacy (Perez-Tornero and Varis, 2010).

There are some careers in which it is important to have media literacy, particularly those that are inserted in the area of communication sciences. The public relations function is one of them, because these types of professionals must purchase a set of critical analysis skills related to the media. In this sense, there is an urgent need to make related decisions to choosing the right channel to reach the audience; understand how multiple channels (email, brochures) reinforce the message (Wilcox and Cameron, 2009). Thereby, it becomes increasingly important to understand what is the investment that has been made, in academic terms, in the Public Relations Degrees. In this study, we intend to understand how the media studies are included in the curricula of Public Relations Degrees and master's degree, in the Portuguese Public Universities. This study becomes innovative, because it analyzes university curricula and specifically in the area of Public Relations. Most of the studies on media literacy in Portugal are focus on children, analysing their school curricula, not considering the university curricula.

\section{The Literatura Review}

\subsection{The Importance of Media Literacy}

The United Nations Educational, Scientific and Cultural Organization [UNESCO] has been playing a very important 
role with regard to the promotion of education for the media (Fedorov, 2014; Pinto, 2014), considering itself to media literacy as a priority for a cultural education of the XXI century (Buckingham, 2003; Fedorov, 2014; Perez-Tornero and Varis, 2010). Thus, this organization have been working a lot of initiatives to promote media literacy (Buckingham, 2001).

The importance of media education was promoted by the UNESCO, in 1982. In this context, they organized several conferences, to discuss the need for the study of media literacy. The first conference took place in Grunwald (1982), Germany ("Grunwald Conference") where they met a group of international experts. During this meeting the experts discussed aspects such as the impact that the media (specifically radio, television, the press and music) could have on training and education of individuals (Buckingham, 2001; Perez-Tornero and Varis, 2010; Pinto, 2014).

In 1990 took place another conference in Toulouse ("Toulouse Conference"). During this conference the experts discussed issues related to the part of education, specifically with a set of guidelines for the development of curricula and specific training of teachers at this level. The third conference was held in 1999 in Vienna ("Vienna Conference"). During this meeting they considered the new communication paradigm related to the digital universe. In this case, the experts debated the importance of new technologies; in addition to the press, cinema, radio and television.

Finally, the fourth conference was held in Seville in 2002 ("Seville Seminar"). This meeting has become relevant to the construction of a shared conceptual framework. It was from this point that international institutions have begun to consider these issues of media literacy (Perez-Tornero and Varis, 2010).

The aspects discussed during the conferences mentioned above have become valid until the present day. In Grunwald's statement (1982) key issues were considered that are currently shared by educators media, and these include: the involvement of all the media (at the level of image-television and movies; the level of the video, the radio; music; the press - newspapers, magazines, and the level of new technologies); learning about the media and not through the media; developing a critical understanding and active participation (Perez-Tornero and Varis, 2010).

The declaration of Grunwald enabled us to realize that the media have come to play an important and powerful role in contemporary societies, and their education should be a prerequisite for the practice of modern citizenship (Perez-Tornero and Varis, 2010). Since this statement that media education has been a focus of interest and activity in several countries (Buckingham, 2001).

Nowadays it is difficult to define the concept of media literacy. This is because it is a complex and multidimensional term (Potter, 2001; Potter, 2010).

On the one hand, there is a diversity of perspectives when we define media literacy (Carvalho, 2015). Moreover, media literacy involves a cognitive; emotional; aesthetic and moral dimension (Potter, 2001; Potter, 2010).

The cognitive dimension refers to a factual information (dates, names, definitions). The emotional dimension involves the feelings (love, joy, frustration). The aesthetic dimension is the way to produce the messages. Finally, the moral dimension is associated with values, that is, to what we associate with the right and/or wrong (Potter, 2001; Potter, 2010).

In general, media education tends to be based on a trilogy of idea, considering, the ability to inform; inform and be informed about the media (Pinto, Pereira, Pereira and Ferreira, 2011).

In this sense, this type of literacy involves not only an ability to use the media, as well as a form of critical thinking in order to understand and/or evaluate the media and its contents, considering the social and cultural processes and different images, languages and representations of the world (DGE, 2014; European Parliament, 2008; Jeong, Cho and Hwang, 2012; Potter, 2001; Perez-Tornero and Varis, 2010; Verniers, 2009; Warnick, 2002). These skills enable individuals to be more effective in problem solving and an improvement in their communication skills; expression and interaction and also civic participation and active citizenship (Perez-Tornero and Varis, 2010).

Media literacy can be defined as: "The set of knowledge, skills and competences (and the processes of the respective acquisition) for the access, use clear, critical research and analysis of the media, as well as the expression of skills and communication through these same media "(Pinto et al., 2011, 24).

It is common to find the concepts of visual literacy and digital literacy associated with the concept of media literacy. It is important to emphasize that they are not synonyms (Potter, 2001).

Audiovisual literacy implies the ability to use and analysis of audiovisual platforms (e.g. television, film). In turn, digital literacy involves the technical skills needed for effective use of digital tools (i.e. new media, new technologies) (Perez-Tornero and Varis, 2010).

Although they are different types of literacy, it is concluded that media literacy encompasses both visual and digital (Potter, 2001). This is because, actually, there is a convergence of media, considering a fusion of digital and analog 
(Buckingham, 2003; DGE, 2014; Perez-Tornero and Varis, 2010; Verniers, 2009). So when we refer to media literacy we refer to digital and analogue platforms simultaneously (Perez-Tornero and Varis, 2010; Verniers, 2009).

Despite the above-mentioned aspects, it must be observed that some authors argue that there is still no consensus on the use of a single name when referring to media literacy. Thus, this type of literacy also tends to be known by "media education"; "Education for communication" (Pinto et al., 2011).

In the 90s it started to be considered the digital and media skills in many countries. This need for media education came mainly due to the increasing information that individuals would be exposed - Information society (Pinto et al., 2011; Perez-Tornero and Varis, 2010). However, the starting point for the acquisition of these skills is related with the awareness of subjects at this level (Jeong, Cho and Hwang, 2012; Perez-Tornero and Varis, 2010).

Thus, it is imperative that individuals become aware of the importance of the media in their daily lives, as well as the influence it can have (Jeong, Cho and Hwang, 2012; Perez-Tornero and Varis, 2010). This consciousness takes into account two main objectives. On the one hand, it should be investigated the importance and influence that the media have on people's everyday lives. On the other hand, the development of essential skills to use this type of communication is necessary, taking into account the objectives and values of each individual (Perez-Tornero and Varis, 2010). In this context, it has emerged the need to innovate and adapt school curriculum, to include media education (DGE, 2014; Pereira 2000; Pinto, 2014; Potter, 2010). According to Buckingham (2003) this inclusion of media literacy began to be considered in the 1960/70.

As mentioned in this study, the media play a key role in the social, political and cultural aspects of modern societies, which makes necessary to educate young people to a critical spirit of what are the media (Pereira, 2000).

In a generic way, individuals feel that they have knowledge in terms of what are the means of communication and its functions, and that media are part of their daily lives. However, they do not realize that they may improve this level (Potter, 2001).

Pereira, Pinto and Moura (2015) confirmed this idea, considering that young people have low media literacy levels. This research had the participation of 679 students from $12^{\text {th }}$ grade public schools from different districts of the country.

In this case, it was found that there is a massive use of media by adolescents. In this way, $99 \%$ of respondents have access to television; $98 \%$ use the computer with internet and/or mobile phones/smartphones; $93 \%$ claim to use "often" or "always" the Internet and $75 \%$ say that use "often" or "always" online social networks. However, these same students demonstrate a difficulty in analyzing and understanding the media. This point was proved, for example, by the fact that the term "body information" was not familiar. This study may be a proof that media education has not been considered in the school curriculum, although some authors reveal the relevance of their inclusion in the study plans (e.g. Perez-Tornero and Varis, 2010). Furthermore, it should be noted that students who have higher levels of media literacy are, most often, those who nurture a greater interest and greater motivation to realize the role that the media take in their lives or those who hold higher levels of cognitive, social and cultural development (Pereira Pinto and Moura, 2015). This information proves, once again, that has not been considered a media education in the school context.

Although in the early of XXI century media literacy have reached a large scale in major world countries. Fedorov (2014) argues that media literacy cannot have spread in the same way in some countries in Europe, Africa and Asia. We argue that, given the results of the previously presented study, Portugal may be constituted as one of those European countries where media literacy is still not considered sharply.

While it is not clear an increased investment in media education in the national context, it is important to recognize its need and relevance. Already in the 60s, McLuhan argued that we would live in an era media bubble, with the appearance of mobile phones, the Internet and online social networks (Perez-Tornero and Varis, 2010).

It is now known that there is no "ideal formula" for creating curriculum that include media literacy. The creation of these syllabi will depend on the own goals of schools and the dominant view of some authors (Potter, 2010). However, the prevailing concern form to inform people regarding the use of the media, to acquire self-defense processes against its risks and threats. This is because the higher the literacy of individuals at this level, the greater is its control and power over the media, and consequently greater control over its own behaviors (Potter, 2001).

In this sense, the concept of media literacy has acquired a scientific and pedagogical dimension in the past 3 decades, with parents, teachers and educators play a crucial and interdependent role in promoting it (Buckingham, 2001; Hobbs, 1998; Pereira, 2000; Potter 2013; Perez-Tornero and Varis, 2010; Tucho, Fernandez-Planells, Lozano and Figueras-Maz, 2015).

Also, as part of media education, has been observed an increased concern for children and young people so they can get to live more independently in a media ubiquitous environment (Pereira, 2000). However, it should be noted that media literacy should be a continuous learning, lifelong achieved (DGE, 2014; Pinto, 2014; Perez-Tornero and Varis, 2010; 
Potter, 2001; Verniers, 2009). According to Buckingham (2001), the key players within the media literacy will not only be teachers, but also the producers of the media themselves (e.g. trade) and regulators of the media. According to the same author, it is necessary to consider the theoretical and practical aspects and intercultural dialogue facing an increasing globalization.

In this sense, the need to understand in which circumstances the media education has been considered in a university context, specifically in public relations courses. This is because the own communication sciences professionals should have critical skills about the use of the media (Tucho et al., 2015).

\subsection{The Importance of Public Relations}

The concept of public relations [PR] emerged in the United States and was the third American president Thomas Jefferson (1743-1826) who uttered this expression for the first time in a Congress. This concept arises as being associated with a set of socio-economic conditions of the time (e.g. existence of a mass circulation press, rapid industrialization). At the end of the $2^{\text {nd }}$ World War the term expands to Europe, having appeared in Portugal with the appearance of some American multinational companies such as Mobil and Shell (Smith, 2011).

There has been, over the years, many settings within what may be understood as PR. In this sense, Rex Harlow (one of the first authors of the concept of public relations and founder of the Public Relations Society of America - PRSA) proceeded to build about 500 definitions from various sources (quoted in Wilcox \& Cameron, 2009).

In this context, Harlow held that the concept of public relations could be understood as the management function which helps establish and maintain mutual lines of communication, understanding, acceptance, cooperation between the organization and its stakeholders; management issues, maintenance information concerning the public, management responsibility to emphasizing in relation to the public interest; consideration of possible changes, anticipating trends and resorting to research and ethical issues as major tools (quoted in Wilcox \& Cameron, 2009).

It has been emphasized by some authors; the management function associated with the concept of public relations. In this context, Grunig and Hunt (1984) and Grunig (1992) defined public relations as the management of communication between the organization and its stakeholders. Grunig (1992) also adds that public relations become useful to the planning, implementation and evaluation of organizational communication with external and internal audiences (groups involved in the fulfillment of objectives).

With the impact of general systems this theory began to take from the $50 \mathrm{~s}$, in the social sciences and it has become pertinent to realize the role of communication in organizations (Gonçalves, 2010). More specifically, it was considered important to realize public relations as a strategic process of two-way communication between an organization (sender) and its public (receiver), considering the interests of both parties (Gonçalves, 2010). This definition of public relations is in line with what was advocated by Grunig and Hunt (1984) in the model "two-way communications." According to these authors would require a mutual understanding and a two-way communication, so that a benefit ratio for the both parties (how the public perceive the organization and what are the consequences for the public derived from organization's actions?). This model began to be used in 1980 and remains until the present day (quoted in Wilcox \& Cameron, 2009).

In addition to the management function associated with the public relations term, it will be important to consider also the bidirectionality and the interest of both parties. So, it is the duty of the public relations professional to establish this two-way relationship between public and organizations (Dennis and DeFleur, 2010). However, it is difficult to define this type of professional, considering the diversity of functions that it performs (Lopes, 2014).

In a general way, it is understood that the public relations professional should be responsible for establishing the relationship between the organization and the public. For this, it is important to develop a set of activities such as: internal communication (with employees); corporate communications (on behalf of the organization); management and organization of events (e.g. conferences and / or symposiums); management of crisis communication (prepare the speech in emergency situations); strategic communications; management of financial relationships (e.g. contacts with investors); analysis/relationship with the media (i.e, communication with journalists, experts and editors of national and international publications and local creation of specific messages to key audiences) (Tench and Yeomans, 2009). To these activities the authors Dennis and DeFleur (2010) and Wilcox and Cameron (2009) add also the marketing communication (i.e., promotion of products and services through specific tools such as new releases, newsletters, reports, events, brochures, average); preparation of executive speeches; research and evaluation (by applying own scientific questionnaires for measuring attitudes and public perceptions); establishing relationships with the community; management of public affairs; responsibility for maintaining organizational reputation (e.g. the organization's website management). It appears that the functions associated with the relationship with the media have been heavily mentioned by the authors of the specialty (Dennis and DeFleur, 2010; Hallahan, 2010; Lopes, 2014; Tench and Yeomans, 2009; 
Wilcox and Cameron, 2009). In this context, it is considered that the area of Media Relations is one of the major areas in the discipline of public relations (Tench and Yeomans, 2009). This is because, on the one hand, one of the ways of public relations have access to the opinions of leaders and key stakeholders is through the mass media (radio, television, newspapers, magazines). On the other hand, are those media which permit broadcast information faster and efficient for large numbers of people, facilitating the formation of public opinion (Cameron and Wilcox, 2009).

Furthermore, the emergence of new media (new information technologies) facilitated the globalization information (Cameron and Wilcox, 2009).

Conducting a study sponsored by PR Week (2006), concluded that the media relations function was the most pointed by the public relations professionals. In this context, they proceeded to the application of a questionnaire to understand what the main activities developed by public relations departments. It was pointed that the media relations function was the most mentioned (79.5\%), followed by the crisis management (62.6\%) and communication with employees $(59.4 \%)$ (quoted in Wilcox and Cameron, 2009).

One of the techniques most used by public relations professionals - involving the media, is called a new release/press release (Dennis and DeFleur, 2010; Wilcox and Cameron, 2009). This began to be used in 1906 and it is a simple document whose main objective is linked to the dissemination of information through the media (magazines, newspapers). As the name suggests, the new release is the digital version of the press release. In addition to this technique, public relations professionals use other techniques such as: media alerts (used to inform the media on a particular event); the media kits (information about a particular product, which is transmitted to editors and reporters to facilitate the drafting of the topic in question); fact sheets (distributed as part of the media kits or with new releases to disclose additional information on a product, person, or event); pitch letters (more condensed information to stimulate the attention of editors) (Wilcox and Cameron, 2009).

Regarding the academic aspect, it is known that higher education in the field of public relations have been introduced in Portugal in the late 80s, comprising in the disciplinary field of communication sciences (Gonçalves, 2010). Therefore, despite the New Professions Institute [INP] have been the pioneer where the first regular course of public relations has emerged, with three semesters in 1964; it was in 1990 that took place the first exclusive course of public relations in Portuguese higher education in the School of Social Communication. This remains today under the name Degree in Public Relations and Corporate Communications. Although in the 90s we have been an extension of offers at this level, in the year 2007-2008 was accounted for 40 courses in communication sciences and only 9 of them have the expression Public Relations. It is clear; therefore, this is a scientific, yet sparsely studied field, which does not invalidate its relevance (Gonçalves, 2010). Wherefore, it arises the need to see how are made the syllabi of such courses and the investment made at the level of media education.

\subsection{The Importance of Media Literacy for the Public Relations Funtion}

For public relations professionals can perform the above activities they will have to purchase a set of critical analysis skills related to the media. In this sense, there is an urgent need to make decisions related to choosing the right channel to reach the audience; understand how multiple channels (email, brochures) reinforce the message (Wilcox and Cameron, 2009).

In the specific case of new releases / press releases are a set of techniques that should be taken into account. Thus, it is necessary to understand what the key message is and who is the public. Furthermore, the drafting of a new release / press release is identical to a story which first paragraph must summarize the most important aspects that are intended to convey, but in a generic way. After writing the first paragraph, the information will be itemized, presenting the new release / press release an inverted pyramidal structure (Wilcox and Cameron, 2009).

It follows, then, that the study of the media is very important to the success of public relations professionals. In this sense, they will need to develop knowledge and critical skills to that level, so they can settle trust and privileged relationships with the media (Hallahan, 2010; Lee, Sha, Dozier and Sargent, 2015; Lofstrom, 2010; Lopes , 2014; Tucho et al., 2015; Wilcox and Cameron, 2009).

In view of the above aspects, it appears that, although still scarce research at the level of media literacy, in relation to professionals and future public relations professionals it is known a study is being conducted on the same level. Accordingly, in order to understand in what way communication professionals would be formed at the level of media literacy, have been analyzed the syllabi of 117 communication area courses in Spanish universities. According to this analysis, only 15 of the 117 courses took account of an education for the media, 9 in Audio-visual Communication area; 5 in Journalism area and only 1 in the field of Advertising and Public Relations. However, interviews with university professors pointed to a need to invest in media literacy of these professionals (Tucho et al., 2015).

Considering the results of the previously presented study, a need to include media education in the curriculum of 
communication courses it is urgent to settle it and that effort is assumed, although this inclusion has not yet happened sharply. Furthermore, it is known, also, that there is little literature and research on the issues concerned, particularly in the national domain. Considering the review of the literature, it is possible to note that in Portugal the studies carried out in the area of media literacy have as main audience the children, considering their school curricula and their education. However, communication professionals and, in particular, Public Relations professionals are known to have close contact with the media when they carry out their tasks in their day-to-day work. This strong and direct contact makes it necessary also for these professionals to acquire the necessary skills and knowledge and, therefore, to have media literacy. It is known that, although this type of research has already been done in Spain, the same is not true in Portugal, making this research very important.

In this context, the need to understand in what sense develops media literacy, specifically in future public relations professionals. Thus, the starting question that guided this study was: what is the investment that has been made by the Portuguese public universities, with regard to media literacy, specifically in public relations courses? To answer this question, we outlined the following objectives:

In a generic way, we intend to understand to what extent the media studies are included in the curricula of Degrees and Master's Degrees in Public Relations, the Portuguese Public Universities. Specifically, it is relevant:

- Analyze the courses on media literacy;

- Understand that the courses on media studies treat of compulsory courses or electives;

- Examine how many ECTS (academic credits) of each of the courses on media literacy;

- Reflecting on the year they are taught the courses on the study of the media.

\section{Method and Procedures}

It is considered that the methodology used in this case was a qualitative methodology, being the researcher the key element of data collection. In this case, it became a reality, only a descriptive analysis of the information collected. In this sense, it is an exploratory study, since the literature on the subject in question is still quite scarce.

The main objective of this research is to understand in what sense there is or there is not an investment of media literacy in public relations courses in Portuguese public universities. In this context, we proceeded to the analysis of the curricula of public relations courses / organizational communication / strategic communication of 15 existing Portuguese public universities, having this information collected by analyzing the websites of the universities. It was considered appropriate a survey of a set of information that allows understanding to what extent is the public relations area courses promote a media education.

So we proceeded to the collection of specific information. Specifically, we analyzed the curricula of undergraduate and public relations master of the 15 existing Portuguese public universities. The procedure used, and the choices associated with it will then be explained below.

To select universities we have resorted to information from the General Directory of Higher Education website [DGES]. Despite the website DGES allow access also to Polytechnic education courses, was decided to choose only universities, considering that this is a study, further exploration. For the same reason, it was decided only by public universities, not having extended to private universities.

In addition, access to a listing of the Portuguese existing public universities has become easier than access to the same information regarding the private Universities. Public Universities analyzed were then the following: ISCTE University Institute of Lisbon; Open University; University of the Azores; University of the Algarve; Aveiro University; University of Beira Interior; Coimbra University; University of Évora; University of Lisbon; University of Madeira; Minho University; New University of Lisbon; Oporto University; Technical University of Lisbon; University of Trás os Montes and Alto Douro.

It is important to note that during the work in question is referred to the public relations term. However, during the collection of data used terms encompassed not only the concept of public relations, as well as the concepts of organizational communication / business and strategic communication. This is because it was realized that, despite the different names, these are quite identical courses, verifying a convergence of their syllabus.

During the collection of information was noticed, too, that some of the communication sciences courses have indicated a focused expertise in the area of public relations / organizational communication / strategic communication.

In this sense, it has become necessary to analyze also the communication sciences courses that have this part of specialization, having girded me only to courses with the specific designation of public relations / organizational communication / strategic communication.

Finally, it should be noted that the collection of information encompassed not only those related courses to Bachelor's 
Degrees, as well as the Masters (including the Integrated Masters).

The choice of courses analyzed (courses that were directly related to media literacy) was based on the "Referential Media Education" (DGE, 2014). Thus, CU's analyzed were those that indicate issues related to: the press; the radio; the television; cinema and the Information and Communication Technology [ICT]. Furthermore, the study took into account another investigation that had been carried out in the same context, the authors Tucho, Fernandez-Planells, Lozano and Figueras-Maz, in Spain, in 2015 (study described above).

Considering the objectives presented, analyzed the syllabi of the courses in the context of public relations. More specifically, the courses on the study of the media, verifying if they are constitued as mandatory or optional; which number your ESCTS; which the school year in which they are taught.

Then the tables that allow a descriptive analysis of the information collected will be presented. Two tables will be displayed. One of the tables involves information concerning the Bachelor's degrees. In turn, the second table set includes the data relating to Masters (including Integrated Masters).

\section{Results}

\subsection{The Investment in media literacy in Public Relations Bachelor's Degrees}

The table allows us to realize that only three of 15 analyzed universities offer a Bachelor's Degree in the field of Public Relations. These three universities are the University of The Azores; University of Madeira and New University of Lisbon. However, it should be noted that one of the universities (New University of Lisbon) has a Bachelor Degree in the field of communication sciences, covering a specific branch related to strategic communication. This issue could be due to the fact that the Portuguese Public Universities do not invest yet significantly in this area, since it is a very specific area of communication sciences. Furthermore, public relations are still a very recent study area, as advocated by some authors (e.g. Gonçalves, 2010).

Regarding the subjects units [SU] taught, becomes possible to understand that, although these same do not present the same kind of description, most of which relates to the media address and history of the media. Furthermore, the training offer that involves the new Media encompasses issues such as digital visual communication. In this sense, it is clear that none of the SUs involves issues such as online social networks. It should be noted that only one of the courses is related to the cinema. I concluded then that has not yet been a significant enforcement on what are the Technology of Information and Communication [TIC], although some authors defend their relevance (e.g. Wilcox and Cameron, 2009). This issue may be due to the fact that this is also a new area, and still there was no reform at this level. In addition, it becomes possible to verify also that there is a greater concern in the media development of study. The media concept is often used in a generic domain, making it difficult to see what kind of media it is. This aspect may be justified because there is still no concrete definition of what media literacy is and which term to use to set the same (Carvalho, 2015; Potter, 2001; Potter, 2010).

Concerning to the year in which these subjects courses are taught, it can be seen that are teached in the 2nd year or 3rd year of degree. However, it was not possible to obtain this information regarding the New University of Lisbon, since it was not available on their website. With this gap in available data it has become a bit complex to reach a conclusion at this level. We realize that only during the 1st year of studies the effort on media literacy of students keeps apart from the curricula. With regard to the hours of courses, it is possible to conclude that the University of the Azores is the one whose endeavor is more significant on media education. On the other hand, New University of Lisbon is where less time is dedicated to this type of literacy. This aspect can be explained by the fact that the University of the Azores offer a minor in communication that turns out to be more general than the strategic communications branch of the New University of Lisbon. We have been watching that the degrees in communication sciences are composed of more courses related to the Media.

Regarding to the specific weight of these subjects related to the importance within the courses, we can observe, generally, a low level of value, being a little more significant at the Bachelor's study program in Communication, Culture and Organization of the University of Madeira. This question can be justified by the relevance of the courses may have or because of certain type of rules imposed by the course coordinator.

Finally, with regard to the character of subjects units, the table analysis shows that only two of the 12 courses presented are optional, and the remaining mandatory. It is possible to conclude, then, that there will always be courses of this kind that are mandatory. Furthermore, despite its optional nature of these courses they have exactly the final weight and the same hours of mandatory SUs.

Hereafter is presented the table for the Degrees taught in the area of public relations / organizational communication / strategic communication. 
Table 1. Literacy in Mediatic Bachelor's Degrees in Public Relations

\begin{tabular}{|c|c|c|c|c|c|c|c|c|}
\hline University & Name of Degree & $\begin{array}{l}\text { Designation of } \\
\text { Specialization }\end{array}$ & Name of $S U$ & $\begin{array}{c}Y e a \\
r\end{array}$ & $\begin{array}{c}\text { Seme } \\
\text { ster }\end{array}$ & $\begin{array}{l}\text { Hours } \\
\text { Course }\end{array}$ & $\begin{array}{r}E C \\
T S \\
\end{array}$ & $\begin{array}{l}\text { Kind } \\
\text { of } S U\end{array}$ \\
\hline $\begin{array}{l}\text { Univ. of the } \\
\text { Azores }\end{array}$ & $\begin{array}{l}\text { Public Relations and } \\
\text { Communication }\end{array}$ & Communication Minor & History of Media & $3^{\text {rd }}$ & $2^{\text {nd }}$ & $\begin{array}{c}168\left(30 \mathrm{~T}^{1} \mathrm{e}\right. \\
\left.30 \mathrm{TP}^{2}\right)\end{array}$ & 6 & $\begin{array}{l}\text { manda } \\
\text { tory }\end{array}$ \\
\hline $\begin{array}{l}\text { Univ. of the } \\
\text { Azores }\end{array}$ & $\begin{array}{l}\text { Public Relations and } \\
\text { Communication }\end{array}$ & Communication Minor & $\begin{array}{l}\text { Sociology of Media and } \\
\text { Information }\end{array}$ & $3^{\text {rd }}$ & $1^{\mathrm{st}}$ & $\begin{array}{c}168 \mathrm{~h}(30 \mathrm{~T} \mathrm{e} \\
30 \mathrm{TP})\end{array}$ & 6 & $\begin{array}{l}\text { manda } \\
\text { tory }\end{array}$ \\
\hline $\begin{array}{l}\text { Univ. of the } \\
\text { Azores }\end{array}$ & $\begin{array}{l}\text { Public Relations and } \\
\text { Communication }\end{array}$ & $\begin{array}{l}\text { Minor in language, } \\
\text { culture and literature }\end{array}$ & Cinema and Literature & $3^{\text {rd }}$ & $1^{\text {st }}$ & $\begin{array}{c}168 \mathrm{~h}(30 \mathrm{~T} \mathrm{e} \\
30 \mathrm{TP})\end{array}$ & 6 & $\begin{array}{l}\text { manda } \\
\text { tory }\end{array}$ \\
\hline $\begin{array}{l}\text { Univ. } \\
\text { Madeira }\end{array}$ & $\begin{array}{l}\text { Communication, Culture } \\
\text { and organizations }\end{array}$ & $\mathrm{N} / \mathrm{a}^{* 3}$ & $\begin{array}{l}\text { Image processing, digital } \\
\text { photography and video }\end{array}$ & $2^{\text {nd }}$ & 2nd & $20 \mathrm{~T} \mathrm{e} 60 \mathrm{TP}$ & 7,5 & $\begin{array}{l}\text { option } \\
\text { al }\end{array}$ \\
\hline $\begin{array}{l}\text { Univ. } \\
\text { Madeira }\end{array}$ & $\begin{array}{l}\text { Communication, Culture } \\
\text { and organizations }\end{array}$ & N/a* & $\begin{array}{lll}\text { Digital Visual } & \text { Commun } \\
\text { ication I } & & \\
\end{array}$ & $3^{\text {rd }}$ & $1^{\mathrm{st}}$ & $20 \mathrm{~T}$ e $60 \mathrm{TP}$ & 7,5 & $\begin{array}{l}\text { manda } \\
\text { tory }\end{array}$ \\
\hline $\begin{array}{l}\text { Univ. } \\
\text { Madeira }\end{array}$ & $\begin{array}{l}\text { Communication, Culture } \\
\text { and organizations }\end{array}$ & N/a* & Analysis of Media Discourse & 2nd & 2nd & $\begin{array}{c}10 \mathrm{OT}^{4} \mathrm{e} \\
72 \mathrm{TP}^{5}\end{array}$ & 7,5 & $\begin{array}{l}\text { manda } \\
\text { tory }\end{array}$ \\
\hline $\begin{array}{l}\text { New University } \\
\text { of Lisbon }\end{array}$ & Communication Sciences & $\begin{array}{l}\text { Branch of strategic } \\
\text { communication }\end{array}$ & Media Discourse & $\begin{array}{l}\mathrm{N} / \mathrm{d} \\
* * 6 \\
\end{array}$ & $\begin{array}{l}\mathrm{N} / \mathrm{d}^{*} \\
*\end{array}$ & $4 \mathrm{~h}$ week & 6 & $\begin{array}{l}\text { manda } \\
\text { tory }\end{array}$ \\
\hline $\begin{array}{l}\text { New University } \\
\text { of Lisbon }\end{array}$ & Communication Sciences & $\begin{array}{l}\text { Branch of strategic } \\
\text { communication }\end{array}$ & Filmology & $\begin{array}{l}\mathrm{N} / \mathrm{d} \\
* *\end{array}$ & $\begin{array}{l}\mathrm{N} / \mathrm{d}^{*} \\
*\end{array}$ & 4h week & 6 & $\begin{array}{l}\text { manda } \\
\text { tory }\end{array}$ \\
\hline $\begin{array}{l}\text { New University } \\
\text { of Lisbon }\end{array}$ & Communication Sciences & $\begin{array}{l}\text { Branch of strategic } \\
\text { communication }\end{array}$ & History of Media & $\begin{array}{l}\mathrm{N} / \mathrm{d} \\
* *\end{array}$ & $\begin{array}{l}\mathrm{N} / \mathrm{d}^{*} \\
*\end{array}$ & 4h week & 6 & $\begin{array}{l}\text { manda } \\
\text { tory }\end{array}$ \\
\hline $\begin{array}{l}\text { New University } \\
\text { of Lisbon }\end{array}$ & Communication Sciences & $\begin{array}{l}\text { Branch of strategic } \\
\text { communication }\end{array}$ & Media Mutation & $\begin{array}{l}\mathrm{N} / \mathrm{d} \\
* *\end{array}$ & $\begin{array}{l}\mathrm{N} / \mathrm{d}^{*} \\
*\end{array}$ & $4 \mathrm{~h}$ week & 6 & $\begin{array}{l}\text { manda } \\
\text { tory }\end{array}$ \\
\hline $\begin{array}{l}\text { New University } \\
\text { of Lisbon }\end{array}$ & Communication Sciences & $\begin{array}{l}\text { Branch of strategic } \\
\text { communication }\end{array}$ & News Theory & $\begin{array}{l}\mathrm{N} / \mathrm{d} \\
* *\end{array}$ & $\begin{array}{l}\mathrm{N} / \mathrm{d}^{*} \\
*\end{array}$ & $4 \mathrm{~h}$ week & 6 & $\begin{array}{l}\text { manda } \\
\text { tory }\end{array}$ \\
\hline $\begin{array}{l}\text { New University } \\
\text { of Lisbon }\end{array}$ & Communication Sciences & $\begin{array}{l}\text { Branch of strategic } \\
\text { communication }\end{array}$ & Argumentation and Media & $\begin{array}{l}\mathrm{N} / \mathrm{d} \\
* *\end{array}$ & $\begin{array}{l}\mathrm{N} / \mathrm{d} * \\
*\end{array}$ & $4 \mathrm{~h}$ week & 6 & $\begin{array}{l}\text { option } \\
\text { al }\end{array}$ \\
\hline
\end{tabular}

\subsection{The investment in media literacy of Masters in Public Relations}

The below table allows us to realize that only four of the 15 analyzed universities offer a Master in the field of public relations. These four universities are the University of Beira Interior; Minho University; New University of Lisbon and University of Trás os Montes and Alto Douro.

However, it is important to note that only the University of Beira Interior has a Master Degree specifically in the area of Public Relations. In this sense, the other universities mentioned above offer a more generic Master in the field of Communication Sciences, with this specialization in Public Relations / Strategic Communication. This aspect there is also, in the case of Degrees and, again, may be due to the fact that Portuguese Universities don't invest significantly in this area, since it is a very specific area ofSciences communication. Furthermore, and as mentioned above, Public Relations are still a very recent study area (Gonçalves, 2010).

Regarding the taught SUs, we observe an important difference found in the case of Degrees, which is it becomes possible to understand that most of them converges in terms of content. This is because it appears that these courses emerge fewer in number when compared to the degree (in the case of Undergraduate there was greater reliance on protected areas on media literacy).

That's because most of the courses focuses on the issue of media relations. These contents become very relevant to a specialization in the field of public relations, particularly for functions that relate to the creation of press releases; new releases; Media alerts; Media kits; fact sheets (Wilcox and Cameron, 2009).

In addition, it is possible to conclude that the formation of Master Degrees already involves aspects related online social networks, and may be due to the fact that this is a degree involving greater specialization.

Concerning the year these courses are taught, it is clear that they are all teached in the 1st year, once the second year is

${ }^{1}$ Theoretical
${ }^{2}$ Theoretical-practical
${ }^{3}$ Not applicable
${ }^{4}$ Tutorial Classes
${ }^{5}$ Theoretical-practical
${ }^{6}$ The website of the university does not have this kind of information 
dedicated for the completion of the dissertation or internship.

To understand whether there is a strong commitment to media literacy in 2nd year of Master, we would have to conduct an analysis of the titles of the dissertations or internship reports, which did not become possible due to time constraints inherent in the realization of this work.

With regard to the workload of the courses, it was concluded that the University of Beira Interior is the one whose bet on media education is higher, specifically regarding the SU press office. On the other hand, New University of Lisbon spends less time dedicated to this type of literacy. This aspect can be explained by the fact that the University of Beria Interior offer a master's degree in strategic communications. It is known that the communication advisory knowledge are extremely important for public relations professional, as has been advocated by several authors (Hallahan, 2010; Lee et al., 2015; Lofstrom, 2010; Lopes, 2014; Wilcox and Cameron, 2009).

In relation to the specific weight of these subject units, it is clear that despite the New University of Lisbon devote less hours to media education, it is one that offers a greater number of ECTS (European Credit Transfer System) to Communication, Media and Organizational Studies; followed by the Minho University with 6.5 ECTS. Most subjects units related to media literacy consist of 6 ECTS. This question may be answered regarding to the rules inherent to the course.

Finally, with regard to the character of Subject Units, the analysis of the table shows that only one of the six courses presented is optional. That is, despite the Master already take into account the issue of online social networks, this course still appears as an optional. All other SUs have an apparently mandatory character.

Hereafter is presented the table for the Master Degrees taught in the area of public relations / organizational communication / strategic communication. This table will be analyzed in the same manner to the above table, regarding to the degree.

Table 2. Media literacy in the Masters of Public Relations

\begin{tabular}{|c|c|c|c|c|c|c|c|c|}
\hline University & $\begin{array}{l}\text { Name of } \\
\text { Degree }\end{array}$ & Designation of Specialization & Name of $S U$ & $\begin{array}{l}\text { Ye } \\
\text { ar }\end{array}$ & $\begin{array}{c}\text { Seme } \\
\text { ster }\end{array}$ & Hours Course & $\begin{array}{l}E C \\
T S\end{array}$ & $\begin{array}{l}\text { Kind } \\
\text { of } S U\end{array}$ \\
\hline Minho University & \begin{tabular}{|l|} 
Communicatio \\
$\mathrm{n}$ Sciences
\end{tabular} & $\begin{array}{l}\text { Branch of Advertisement and } \\
\text { Public Relations }\end{array}$ & Press Office & \begin{tabular}{|l|}
$1 \mathrm{~s}$ \\
$\mathrm{t}$ \\
\end{tabular} & 2nd & \begin{tabular}{|l|l|}
15 OT and \\
$30 \mathrm{TP}$
\end{tabular} & 7,5 & \begin{tabular}{|l|}
$\begin{array}{l}\text { manda } \\
\text { tory }\end{array}$ \\
\end{tabular} \\
\hline Minho University & \begin{tabular}{|l|}
$\begin{array}{l}\text { Communicatio } \\
\mathrm{n} \text { Sciences }\end{array}$ \\
\end{tabular} & $\begin{array}{l}\text { Branch of Advertisement and } \\
\text { Public Relations }\end{array}$ & Digital Strategy & \begin{tabular}{|l|}
$1 \mathrm{~s}$ \\
$\mathrm{t}$ \\
\end{tabular} & 2nd & \begin{tabular}{|l|l|}
15 OT and \\
$30 \mathrm{TP}$
\end{tabular} & 7,5 & \begin{tabular}{|l|l}
$\begin{array}{l}\text { manda } \\
\text { tory }\end{array}$ \\
\end{tabular} \\
\hline Minho University & \begin{tabular}{|l|}
$\begin{array}{l}\text { Communicatio } \\
\mathrm{n} \text { Sciences }\end{array}$ \\
\end{tabular} & $\begin{array}{l}\text { Branch of Advertisement and } \\
\text { Public Relations }\end{array}$ & Internet and Social Network & \begin{tabular}{|l|}
$1 \mathrm{~s}$ \\
$\mathrm{t}$ \\
\end{tabular} & $2^{\text {nd }}$ & \begin{tabular}{|l|l|}
15 OT and \\
$30 \mathrm{TP}$
\end{tabular} & 7,5 & \begin{tabular}{|l|} 
Option \\
al \\
\end{tabular} \\
\hline $\begin{array}{ll}\text { New University of } \\
\text { Lisbon }\end{array}$ & $\begin{array}{l}\begin{array}{l}\text { Communicatio } \\
\text { n Sciences }\end{array} \\
\end{array}$ & $\begin{array}{l}\text { Specialization in Strategic } \\
\text { Communication }\end{array}$ & $\begin{array}{l}\text { Communication, Media and } \\
\text { Organizational Studies }\end{array}$ & $\begin{array}{ll}\mathrm{N} / \\
\mathrm{d}\end{array}$ & $\mathrm{N} / \mathrm{d}$ & $\begin{array}{l}\text { 3h schooltime } \\
\text { and } 1 \text { OT }\end{array}$ & 10 & \begin{tabular}{|l|} 
Manda \\
tory
\end{tabular} \\
\hline $\begin{array}{lr}\text { Univ. } & \text { of } \\
\text { Trás-os-Montes } & \text { and } \\
\text { Alto Douro } & \\
\end{array}$ & $\begin{array}{l}\text { Communicatio } \\
\mathrm{n} \text { Sciences }\end{array}$ & $\begin{array}{l}\text { Specialization in Public } \\
\text { Relations and Advertisement }\end{array}$ & Media and Culture & $\begin{array}{l}1 \mathrm{~s} \\
\mathrm{t}\end{array}$ & $1 \mathrm{st}$ & $\mathrm{N} / \mathrm{d}$ & 6 & $\begin{array}{l}\text { Manda } \\
\text { tory* }\end{array}$ \\
\hline
\end{tabular}

\section{Discussion}

\subsection{Theoretical and Practical implications}

It is considered that the study in question may present theoretical and practical implications. At a theoretical level, it became possible to confirm the importance of media literacy, specifically in the field of public relations function. The literature review on the theme concluded that there is an interdependence relationship between public relations professionals and the media. Firstly, the media allow the disclosure of certain information. On the other hand, are public relations professionals who often are responsible for the preparation of such information (e.g. press releases) (Dennis and DeFleur, 2010; Wilcox and Cameron, 2009).

Furthermore, it was found that this paper presents an innovative character. This is because the research at this level is still scarce, given the small number of studies on media literacy in the context of public relations. It is known that the investigations that have been carried out mainly involve children or young people in secondary education. Thus, media education in higher education has not been the target of study.

Despite this little research at higher education level, some authors have been advocating the idea that media education throughout life is required (DGE, 2014; Pinto, 2014; Perez-Tornero and Varis, 2010; Potter, 2001; Verniers, 2009). This aspect can prove also the innovative nature of this work, since it is confined not only to media literacy in children and / or young secondary school. Another aspect that could be constituted as a theoretical implication of this study relates to the fact that has enabled a survey of public relations courses existing at the level of the Portuguese public universities. 
These data allow for an analysis not only on the investment in public relations courses, and on the curricula of those courses. Specifically, it became possible to see in what extent there is a media education. This aspect is constituted as relevant, since the European Commission has been advocating the need for media literacy at the level of school curricula (Pinto, 2014).

On a practical level it is considered that the work in question may constitute useful for the promotion of best practices in the field of public relations profession. It is known that media literacy enables development of critical thinking (Jeong, Cho and Hwang, 2012; Pereira Pinto and Moura, 2015; Perez-Tornero \& Varis, 2010). This development may be useful to solve certain complex problems.

Furthermore, the media education has been seen as relevant to communication between employees in organizations (eg contact physically distant colleagues) (Perez-Tornero and Varis, 2010). In this sense, a public relations professional who holds greater media literacy can perform its functions more effectively.

\subsection{Limitations and Further Studies}

It is considered that the present study may have limitations, especially with regard to the process of collection and analysis of data.

First, it is relevant to note that it was not possible to deepen the aspects related to the curriculum of courses on media literacy. This is because it showed only the names of subject units, and has not been analyzed what will be covered when they are taught. This gap arises mainly because the goal of the research is to see to what extent there would be a focus on media education in a more quantitative or qualitative way.

Furthermore, and as has been mentioned throughout the work, the time constraints for the completion of the investigation, did not allow me to deepen some aspects. Thus, it is suggested that in future studies a more comprehensive analysis is carried out in this area, producing, for example, interviews with directors of the courses and / or the students themselves.

Another limitation to be mentioned relates to the fact that sometimes have occurred a difficulty to the access level to some data. In this sense, some websites of some universities had no relevant information (e.g. the year and the semester in which the SUs were taught). This lack of information did not allow the analysis of the data as if it were completely homogeneous. Again, it would be important to the realization of interviews with directors of the courses, to have a privileged access to such data.

We emphasize that the review process had a character bit extended.

On the one hand, they were considered only the undergraduate and master's degrees, post-graduate disregarding. On the other hand, were analyzed only public universities, disregarding private universities and polytechnics. In this sense, it is suggested for future studies conducting research to enable the comparison between public universities, polytechnics and private universities.

Finally, it is considered important that the new studies in the field of media literacy and, in the context of public relations, imposed on the professionals themselves and not only on the students. This will be relevant to understand in what way the organizations are committed to training at this level. This is because, as has been advocated by some authors (e.g. DGE, 2014; Pinto, 2014; Perez-Tornero and Varis, 2010; Verniers, 2009) is important to media education throughout life.

\subsection{Critical Reflection}

This study had as main objective to understand what is the investment that have been made by the Portuguese public universities in what concerns to media literacy, specifically in the Degrees and Master Degrees of the Public Relations area.

The data showed that there is still little investment at this level. Of the 15 Portuguese public universities analyzed, only three universities hold courses on media education in their curricula, within the degree in public relations / organizational communication / strategic communication. With regard to masters, it was found that only four of the 15 Portuguese public universities took account of media literacy in their curricula. However, it is important to note that most of these courses had a mandatory character, having a number of ECTS and workload identical to the other SUs courses.

It was observed that there is a greater number of universities focusing on media literacy in the masters than in degrees. However, there were a greater number of courses on media education among graduates. This aspect can be justified on one hand by the fact that the masters have a more specific nature than the degree and on the other hand, because the degree is composed of a greater number of academic years than the master.

Generally, it must be observed that the New University of Lisbon is the one that invests in media literacy at the level of 
bachelor and masters simultaneously.

We conclude that the results of this study are in line with work carried out previously in the promotion of media literacy. However, the investigation concerned an innovation feature, as it focuses on higher education and specifically in the public relations area.

In a generic way, this research became important to realize what is the media literacy, how relevant and possible practical application proposes, suggesting also future studies at that level.

Specifically, the realization of this work allowed me a deepening of knowledge of what can be understood by media literacy, knowledge that these have become quite relevant to my academic future. This is because I have been mostly working in the area of organizational communication and the concept of media literacy is something new for me. However, it should be noted that the lesson taught in this area and the materials recommended by the teacher of the course were very useful for completing the work in question.

\section{Acknowledgement}

This publication is co-financed by the European Social Fund (ESF), through the Human Potential Operational Program $(\mathrm{POPH})$ and national funds of the Ministry of Education and Science (MEC), through the FCT (Foundation for Science and Technology).

\section{References}

Buckingham, D. (2001). Media Education: A Global Strategy for Development. London: UNESCO Sector of communication and information.

Buckingham, D. (2003). Media Education: Literacy, Learning and Contemporary Culture. Cambridge: Polity Press.

Carvalho, A. (2015). Evaluation of Media Literacy Levels: Exploratory Study with Adults in the Labor Market. Master Dissertation. Minho University, Portugal.

Dennis, E., \& DeFleur, M. (2010). Understanding Media in the Digital Age: connections for communication, society and culture. New York: Allyn \& Bacon.

DGE, General Direction of Education. (2014). Referencial of Media Education. Accessed in: http://www.dge.mec.pt/sites/default/files/ficheiros/referencial_educacao_media_2014.pdf

European Parliament (ed.). (2008). Media Literacy in a Digital World. Resolution of 16 December (2008/2129-INI).

Fedorov, A. (2014). Media Education Literacy in the World: Trends. European Researcher, 67(1-2), 176-187. https://doi.org/10.13187/issn. 2219-8229

Gonçalves, G. (2010). Introduction to Public Relations Theory. Oporto: Oporto Editor.

Grunig, J. (1992). Communication, Public relations, and Effective Organizations: an overview of the book. In J. Grunig (Eds), Excellence in Public Relations and Communication Management (1-28). New Jersey: Lawrence Erlbaum Associates.

Grunig, J., \& Hunt, T. (1984). Managing Public Relations. New Jersey: Lawrence Erlbaum Associates.

Hallahan, K. (2010). Public Relations Media. In R. Heath (Eds), The Sage Handbook of Public Relations, (623-641). United States of America: SAGE.

Hobbs, R. (1998). The seven great debates in the media literacy movement. Journal of communication, 48(1), 16-21. https://doi.org/10.1111/j.1460-2466.1998.tb02734.x

Jeong, S. H., Cho, H., \& Hwang, Y. (2012). Media Literacy Interventions: A Meta-analytic review. Journal of communication, 62, 454-472. https://doi.org/10.1111/j.1460-2466.2012.01643.x

Lee, N., Sha, B. L., Dozier, D., \& Sargent, P. (2015). The Role of New Public Relations Practitioners as Social Media Experts. Public Relations Review, 41, 411-413. https://doi.org/10.1016/j.pubrev.2015.05.002

Lofstrom, J. (2010). A Collaborative Approach for Media Training between Technical Communication and Public Relations. IEEE Transactions on Professional Communication, 53(2), 164-173. https://doi.org/10.1109/TPC.2010.2046091

Lopes, L. (2014). Beyond the Journalists: Influencer Relations, a New Era of Media Relations. Master Dissertation. School of Social Communication, Portugal.

Pereira, S. (2000). Education for the Media Today - Some Fundamental Principles. Communication and Society, 14(1-2), 669-674. https://doi.org/10.17231/comsoc.2(2000).1428 
Pereira, S., Pinto, M., \& Moura, P. (2015). Levels of Media Literacy: Exploratory studies with young people of the 12th grade. Minho University: CECS Books [e-book].

Perez-Tornero, J. M., \& Varis, T. (2010). Media Literacy and New Humanism. Moscow: UNESCO, Institute for Information Techonologies in Education.

Pinto, M. (2014). Empowering citizens through media literacy education. Atas do I Council of Europe Platform Exchange on Culture and Digitisation, Baku: Azerbaijan.

Pinto, M., Pereira, S., Pereira, L., \& Ferreira, T. (2011). Education for the Media in Portugal: Experiences, Actors and Contexts. Lisbon: Regulatory Entity for Social Communication.

Potter, J. (2001). Media Literacy. Thousand Oaks: Sage.

Potter, J. (2010). The State of Media Literacy. Journal of Broadcasting \& Eletronic Media, 54(4), 675-696. https://doi.org/10.1080/08838151.2011.521462

Potter, J. (2013). Review of Literature on Media Literacy. Sociology Compass, 7(6), 417-435. https://doi.org/10.1111/soc4.12041

Tench, R., \& Yeomans, L. (2009). Exploring Public Relations (2ºd). U.K.: Pearson Education.

Tucho, F., Fernandez-Planells, A., Lozano, M., \& Figueras-Maz, M. (2015). Media Education, a pending issue in the training of journalists, advertising and audiovisual communicators. Latin Magazine of Social Communication, 70, 689-702. https://doi.org/10.4185/RLCS-2015-1066

Verniers, P. (2009). Lifelong Media Literacy: modelling practices. In P. Verniers (Eds), Media Literacy in Europe: Controversies, Challenges and Perspetives (157-160). Brussels: EuroMeduc.

Warnick, B. (2002). Critical Literacy in a Digital Era: Techonology, Rhetoric, and the Public Interest. New Jersey: Lawrence Erlbaum Associates. https://doi.org/10.4324/9781410603838

Wilcox, D., \& Cameron, G. (2009). Public Relations: Strategies and Tactics. Boston: Pearson.

\section{Copyrights}

Copyright for this article is retained by the author(s), with first publication rights granted to the journal.

This is an open-access article distributed under the terms and conditions of the Creative Commons Attribution license which permits unrestricted use, distribution, and reproduction in any medium, provided the original work is properly cited. 